\title{
A stomatin-like protein encoded by the s/p gene of Rhizobium etli is required for nodulation competitiveness on the common bean
}

\author{
Zerong You, ${ }^{1,2}$ Xuefeng Gao, ${ }^{1}+$ Mei M. Ho ${ }^{3}$ and Dulal Borthakur'
}

Author for correspondence: Dulal Borthakur. Tel: +1 8089566600 . Fax: +1 8089563542. e-mail: dulal@hawaii.edu

\footnotetext{
1,2 Departments of Plant Molecular Physiology ${ }^{1}$ and Microbiology2, University of Hawaii, Honolulu, HI 96822, USA

3 Department of Medicine, Rayne Institute, London WC1E 6JJ, UK
}

\begin{abstract}
Rhizobium etli strain TAL182 is a competitive strain for effective nodulation of beans. From this strain, a novel gene was isolated, s/p, which is 669 bp in size and required for nodulation competition on the common bean. The s/p knockout mutant of TAL182 is defective in nodulation competition, shows reduced growth in the presence of $200 \mathrm{mM} \mathrm{NaCl}, \mathrm{KCl}$ or $\mathrm{LiCl}$ and is complemented by the cloned s/p gene. The deduced amino acid sequence of s/p shows 66-72\% similarity to stomatin proteins of Homo sapiens, Mus musculus and Caenorhabditis elegans. Expression of slp in Escherichia coli from a T7 promoter shows a $26 \mathrm{kDa}$ protein which cross-reacts with human-stomatinspecific polyclonal antibody. Like the human stomatin protein, the s/p-deduced protein, SIp, is very hydrophilic except for a single hydrophobic membranespanning domain. Among various bean-nodulating rhizobia, s/p is present in R. etli, Rhizobium leguminosarum bv. phaseoli and Rhizobium tropici type A strains but is absent in $R$. tropici type B strains. It is also absent in Bradyrhizobium and several other Rhizobium spp.
\end{abstract}

Keywords: nodulation competition, legume, symbiosis, nitrogen fixation, rhizobia

\section{INTRODUCTION}

Soil bacteria of the genera Rhizobium, Bradyrhizobium, Azorbizobium and Sinorhizobium, commonly known as rhizobia, form nitrogen-fixing symbiotic associations with members of the plant family Leguminosae. Rhizobial interaction with legumes requires continuous exchange of signals between the two partners. Rhizobial nod genes are induced in response to the inducer molecules flavonoids, present in the legume root exudate (for review, see Long, 1996). The products of the nod genes direct the synthesis of signal molecules, lipooligosaccharide Nod factors, which induce several physiological responses in the legumes, such as root hair curling, infection thread formation and localized cortical cell division resulting in nodule initiation. A second signal generated within the plant in response to the

\footnotetext{
†Present address: Stratagene Cloning Systems, $11011 \mathrm{~N}$. Torrey Pines Road, La Jolla, CA 92037, USA.

The GenBank accession number for the nucleotide sequence reported in this paper is AF034831.
}

rhizobial Nod factor may elicit further nodule morphogenesis (Hirsch, 1992). Rhizobia then invade through the infection thread where they continue to divide, nourished by the nutrients supplied by the plant, and finally reach the developing nodule. This invasion process involves the coordinated expression of many rhizobial and plant genes. While some of the Rhizobium genes involved in this process, such as $n d v$ and exo, have been characterized (for review, see Leigh \& Coplin, 1992), there are other, as yet unidentified, genes which may be involved in the regulation of growth of rhizobia through infection thread and nodule invasion. This class of genes may determine the capacity of a Rbizobium strain to compete for nodule occupancy.

Competition for nodule occupancy is an interesting biological phenomenon which is considered to be a limiting step for field legume inoculation. Inoculant strains often have to compete with indigenous rhizobia that may be unable to fix nitrogen in symbiosis. At present, little is known about the molecular basis of competitiveness and the genes that are involved in this process. Beattie \& Handelsman (1993) described a 
strategy to identify nodulation competitiveness genes in R hizobium etli. Recently, Mavingui et al. (1997) selected a competitive derivative of Rhizobium strain CFN299 by several cycles of selection for increased competitiveness for nodule formation among derivatives containing randomly amplified DNA regions. Previously, two Sinorbizobium meliloti genes, $n f e 1$ and $n f e 2$, involved in nodulation efficiency and competitiveness were identified and characterized (Sanjuan \& Olivares, 1991; Soto et al., 1993). Another gene, nfeC, essential for nodulation competitiveness on soybean has been isolated and characterized from Bradyrhizobium japonicum (Chun \& Stacey, 1994). Recently, we have shown that mimosine, a toxin produced by the tree legume Leucaena, provides a nodulation competition advantage to mimosine-degrading Rhizobium strains (Soedarjo \& Borthakur, 1998).

$R$. etli TAL182 is a competitive strain for nodulation of the common bean and carries four indigenous plasmids with sizes ranging between 100 and $250 \mathrm{MDa}$. Previously, Borthakur \& Gao (1996) isolated two overlapping cosmid clones containing genes for nodulation competition from the genomic library of $R$. etli strain TAL182 by functional complementation of Rhizobium sp. strain TAL1145, which nodulates bean but is noncompetitive for nodule occupancy. By site-directed Tn5 insertion mutagenesis and subcloning, the genes for nodulation competition were localized within a $4.6 \mathrm{~kb}$ HindIII fragment common to both cosmids. Competition-defective mutants of TAL182 containing Tn5 insertions within the $4.6 \mathrm{~kb}$ HindIII fragment were identified. The competition defect of one of these mutants, RUH120, was complemented by plasmid pUHR207 containing the $4.6 \mathrm{~kb}$ HindIII fragment cloned in a broad-host-range plasmid vector. Thus it was shown that the $4.6 \mathrm{~kb}$ HindIII fragment in pUHR207 contained a gene or genes required for nodulation competition on beans. The objective of the present investigation was to characterize the genes for nodulation competition present in this DNA fragment. Interestingly, one of the genes in the $4.6 \mathrm{~kb}$ HindIII fragment in pUHR207 shows high sequence similarities with the human and murine stomatin genes at the amino acid level. Stomatin is an integral membrane protein in the red blood cells and is involved in the regulation of ion transport (Stewart, 1997).

\section{METHODS}

Bacterial strains and plasmids. Rhizobium strains and plasmids used in this study are listed with their sources and relevant properties in Table 1. Rhizobium tropici strains used in Southern hybridization were described previously by Martínez-Romero et al. (1991).

Bacterial media and growth conditions. Bacterial media, culture conditions and crosses were as described previously by George et al. (1994). For determining the growth rates, Rhizobium strains were grown in minimal medium (MM) which is based on the minimal medium described by Thorne $\&$ Williams (1997) and contains the following $\left(1^{-1}\right)$ : MOPS
(8.37 g, pH 7.2), $\mathrm{KOH}(1.2 \mathrm{~g}), \mathrm{CaCl}_{2}(1.12 \mathrm{~g}), \mathrm{MgSO}_{4}(0.48 \mathrm{~g})$, $\mathrm{NH}_{4} \mathrm{Cl}(1.07 \mathrm{~g}), \mathrm{K}_{2} \mathrm{HPO}_{4}(0.21 \mathrm{~g}), \mathrm{KH}_{2} \mathrm{PO}_{4}(0.05 \mathrm{~g})$, mannitol $(2.5 \mathrm{~g}), \mathrm{NaCl}(5 \mathrm{mg}), \mathrm{H}_{3} \mathrm{BO}_{3}(1 \mathrm{mg}), \mathrm{ZnSO}_{4} .7 \mathrm{H}_{2} \mathrm{O}(1 \mathrm{mg})$, $\mathrm{CuSO}_{4}(0.5 \mathrm{mg}), \mathrm{MnCl}_{2} .4 \mathrm{H}_{2} \mathrm{O}(0.5 \mathrm{mg}), \mathrm{NaMoO}_{4} .2 \mathrm{H}_{2} \mathrm{O}$ $(1 \mathrm{mg})$, EDTA $(10 \mathrm{mg})$, thiamin $(0.2 \mathrm{mg})$, pantothenate $(0.01 \mathrm{mg})$ and biotin $(0.2 \mathrm{mg})$. Rhizobium strains were grown by inoculating $50 \mathrm{ml} \mathrm{MM}$ in $250 \mathrm{ml}$ screw-cap bottles with $0.5 \mathrm{ml}$ Rhizobium culture. Each treatment was replicated three times. Cultures were grown at $28{ }^{\circ} \mathrm{C}$ with shaking, and growth was determined at $12 \mathrm{~h}$ intervals by measuring the $\mathrm{OD}_{600}$ in a Spectronic 401 spectrophotometer. Escherichia coli strains were grown in Luria-Bertani (LB) medium (Sambrook et al., 1989). For determining osmotic stress tolerance, cultures were grown in $\mathrm{MM}$ medium to an $\mathrm{OD}_{600}$ of 0.5 , at which point osmotic shock was applied by addition of a $\mathrm{NaCl}$ solution to a final concentration of $2.5 \mathrm{M}$ and survival was monitored over a period of $3 \mathrm{~h}$ by plating for viable counting (Thorne $\&$ Williams, 1997).

Southern hybridization. Genomic DNA (approximately $3 \mu \mathrm{g}$ ) was digested with EcoRI, electrophoresed on a $1.0 \%$ agarose gel and transferred to a nylon membrane. For Southern hybridizations, DNA probes were labelled by random priming using a digoxigenin labelling and detection kit (Boehringer Mannheim). Digoxigenin-labelled probes were used for hybridization at $42{ }^{\circ} \mathrm{C}$ in a buffer containing $5 \times$ SSC, $0.02 \%$ SDS, $2 \%$ blocking reagent and $50 \%$ formamide $(1 \times$ SSC is $0.15 \mathrm{M} \mathrm{NaCl}, 15 \mathrm{mM}$ sodium citrate) for $12 \mathrm{~h}$ and washed at $60{ }^{\circ} \mathrm{C}$ with $2 \times$ SSC, $0 \cdot 1 \%$ SDS for $30 \mathrm{~min}$. Chemiluminescent alkaline phosphatase substrate Lumi-Phos 530 (Boehringer Mannheim) was used to detect the signal by exposure to X-ray film.

DNA sequence analysis. The $4.6 \mathrm{~kb}$ HindIII fragment of plasmid pUHR207 was sequenced in both orientations. Another $300 \mathrm{bp}$ region adjacent to the left end of the $4.6 \mathrm{~kb}$ HindIII fragment was sequenced from the $14.7 \mathrm{~kb} \mathrm{BamHI}$ fragment of pUHR200 subcloned in pUC18 (Fig. 1). Sequencing was done by a combination of subcloning and primer walking. The $4.6 \mathrm{~kb}$ HindIII fragment and its various SalI, PstI, EcoRI, PstI-EcoRI and EcoRI-HindIII subfragments were cloned in pUC18 and sequenced using the $\mathrm{pUC} / \mathrm{m} 13$ forward and reverse primers with an automated DNA sequencer (model 373A; Applied Biosystems) at the Biotechnology and Molecular Biology Instrumentation $\mathrm{Fa}$ cilities, University of Hawaii. The gaps in the sequence were filled in by sequences generated by using specific inner primers. The sequencing data were analysed by the GCG software and the Experimental BLAST Network Service (Altschul et al., 1990). Protein sequence alignment was performed with the CLUSTAL $w$ and Boxshade Server programs.

Insertional inactivation of orf1 and the s/p gene in TAL182. To inactivate orf1, the $1.0 \mathrm{~kb}$ PstI fragment of pUHR207 containing a middle segment of orf1 (Fig. 1) was cloned in pBR322 and transferred to TAL182 by conjugation. As pBR322 cannot replicate in Rhizobium, it was expected that a single recombination between the cloned fragment and the corresponding homologous DNA in TAL182 would result in the interruption of orf 1 by the pBR322 sequences. Three tetracycline-resistant colonies were screened by Southern analysis and two of them were found to contain the insertion of pBR322 sequences in the expected position. One such colony in which orf1 was found to be interrupted was selected as mutant RUH127. Similarly, to inactivate the slp gene, the $1.7 \mathrm{~kb}$ EcoRI-HindIII fragment of pUHR207 containing this gene (Fig. 1) was cloned in pUC18 and a $2.0 \mathrm{~kb}$ kanamycinresistance cassette $\left(\mathrm{Kan}^{\mathrm{R}}\right)$ from plasmid pSK101 (Shapira et 
Table 1. Bacterial strains and plasmids

\begin{tabular}{|c|c|c|}
\hline Strain/plasmid & Relevant characteristics & Reference/source \\
\hline \multicolumn{3}{|l|}{ Strains } \\
\hline \multicolumn{3}{|l|}{ Rhizobium } \\
\hline TAL182 & R. etli wild-type strain, Rif ${ }^{\mathrm{R}}$ & George et al. (1992) \\
\hline TAL1145 & Leucaena-nodulating Rhizobium sp., Rif ${ }^{\mathrm{R}}$ & George et al. (1994) \\
\hline RUH120 & $\begin{array}{l}\text { Tn5-insertion mutant of TAL182, competition- } \\
\text { defective, } \text { Rif }^{R} \operatorname{Kan}^{R}\end{array}$ & Borthakur \& Gao (1996) \\
\hline RUH126 & $\begin{array}{l}\text { slp mutant of TAL182 with } \mathrm{Kan}^{\mathrm{R}} \text { cassette } \\
\text { inserted }\end{array}$ & This study \\
\hline RUH127 & $\begin{array}{l}\text { orf1 mutant of TAL182 with pBR322 inserted, } \\
\text { Tet }^{R}\end{array}$ & This study \\
\hline \multicolumn{3}{|l|}{ E. coli } \\
\hline BL21(DE3)pLysS & $\begin{array}{l}\text { Contains a lambda prophage with an IPTG- } \\
\text { inducible T7 RNA polymerase gene }\end{array}$ & Studier \& Moffat (1986) \\
\hline \multicolumn{3}{|c|}{ (5) } \\
\hline pUHR68 & $\begin{array}{l}\text { Cosmid clone containing TAL182 DNA } \\
\text { involved in nodulation competition }\end{array}$ & Borthakur \& Gao (1996) \\
\hline pUHR200 & $\begin{array}{l}14 \cdot 7 \mathrm{~kb} \mathrm{BamHI} \text { fragment of pUHR } 68 \text { cloned in } \\
\text { the wide-host-range vector pTR } 102\end{array}$ & Borthakur \& Gao (1996) \\
\hline pUHR207 & $\begin{array}{l}4.6 \mathrm{~kb} \text { HindIII fragment of pUHR } 68 \text { cloned in } \\
\text { the wide-host-range vector pTR } 102\end{array}$ & Borthakur \& Gao (1996) \\
\hline $\mathrm{pET} 21 \mathrm{a}(+)$ & $\mathrm{T} 7$ expression vector, $\mathrm{Amp}^{\mathrm{R}}$ & Novagen \\
\hline pET21-669 & slp gene cloned in pET21(+) & This study \\
\hline pSK101 & $\operatorname{Kan}^{\mathrm{R}}$ cassette from $\operatorname{Tn} 5$ cloned in pUC6 & Shapira et al. (1983) \\
\hline
\end{tabular}

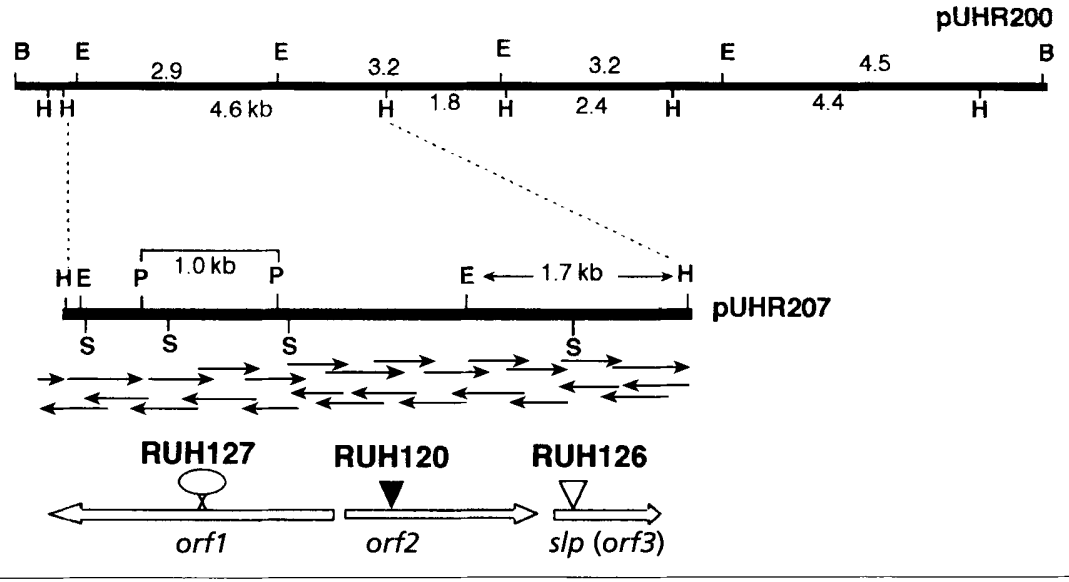
Fig. 1. Restriction maps of the $14.7 \mathrm{~kb}$ BamHI fragment and the $4.6 \mathrm{~kb}$ HindlII fragment cloned in plasmids pUHR200 and pUHR207, respectively. The numbers in pUHR200 indicate sizes of DNA fragments in $\mathrm{kb}$. The sequencing strategy is shown by horizontal arrows below pUHR207. The dimensions and directions of the three ORFs are indicated with open arrows below pUHR207. The positions of the Tn5 insertion in RUH120 (filled triangle) and the $\mathrm{Kan}^{\mathrm{R}}$ cassette insertion in mutant RUH126 (open triangle) and the approximate position of the pBR322 insertion in RUH127 (open circle) are shown. B, BamHI; E, EcoRI; H, HindIII; P, Pstl; S, Sall.

al., 1983) was cloned into the SalI cleavage site, located $92 \mathrm{bp}$ downstream from the ATG start codon of the slp gene in the $1.7 \mathrm{~kb}$ fragment. The interrupted gene, slp:: $\operatorname{Kan}^{\mathrm{R}}$, in the $3.7 \mathrm{~kb}$ EcoRI-HindIII fragment $(1.7 \mathrm{~kb}$ fragment with the $2.0 \mathrm{~kb} \mathrm{Kan}{ }^{\mathrm{R}}$ cassette) from this plasmid was cloned into a wide-host-range plasmid and transferred into TAL182. The slp:: $\operatorname{Kan}^{\mathrm{R}}$ allele was homogenotized by double homologous recombination to obtain mutant RUH126.

PCR amplification of the s/p gene. PCR-amplified fragments were used for cloning and generating probes for Southern hybridization. The PCR reactions were done using the GeneAmp PCR system 2400 (Perkin Elmer). Standard PCR reactions were done in a final volume of $50 \mu \mathrm{l}$ which included $100 \mathrm{ng}$ sample DNA, $200 \mu \mathrm{M}$ each of dATP, dCTP, dGTP and
dTTP, $0 \cdot 2 \mu \mathrm{M}$ of each specific primer, $2.5 \mathrm{mM} \mathrm{MgCl}_{2}$ and 1.5 U Taq polymerase (Promega). 'Hot start' at $94{ }^{\circ} \mathrm{C}$ for $5 \mathrm{~min}$ was used to avoid non-specific DNA amplification. Thermal cycling was done as follows for 25 cycles: denaturation for $30 \mathrm{~s}$ at $94^{\circ} \mathrm{C}$, primer annealing at $60^{\circ} \mathrm{C}$ for $30 \mathrm{~s}$ and extension at $72^{\circ} \mathrm{C}$ for $30 \mathrm{~s}$. For Southern hybridization a $576 \mathrm{bp}$ fragment of the $s l p$ gene was amplified using primers 5' GAG TCA AGG GAC CCG GCT TGAT 3' and $5^{\prime}$ CTC CAT CGG GAA GGG GAA TAA 3'. For cloning the entire $669 \mathrm{bp}$ slp gene with an added NdeI restriction site before the ATG start codon and a BamHI site after the TGA stop codon, the following two primers were used: $5^{\prime}$ GGC ATA TGA ACG CGG CGT CGT TCA CA $3^{\prime}$ and $5^{\prime}$ CAG GAT CCT CAC TTC GGC TTA ATG GCC ATT $3{ }^{\prime}$. 
Expression of $\boldsymbol{R}$. etli SIp in $\boldsymbol{E}$. coli. A PCR product containing the $R$. etli slp gene was cloned between the $N d e I$ and the $B a m \mathrm{HI}$ sites of expression vector $\mathrm{pET} 21 \mathrm{a}(+)$ (Novagen). The plasmid thus constructed was named pET21-669. Plasmid pET21-669 was used to transform the E. coli strain BL21(DE3)pLysS. This strain contains an inducible T7 RNA polymerase gene behind the E. coli lacZ promoter and the plasmid pLys which encodes $\mathrm{T} 7$ lysozyme and represses the background levels of T7 RNA polymerase expression (Studier \& Moffatt, 1986). The transformant was grown in LB broth to an optical density of 0.6 before the $\mathrm{T} 7$ polymerase was induced by adding IPTG to a final concentration of $1 \mathrm{mM}$ with growth for additional $2-3 \mathrm{~h}$. The cells from induced and uninduced cultures were then harvested and lysed and the total proteins were separated on a $12 \%$ polyacrylamide gel. The gel was stained with Coomassie Blue.

Western blot analysis. The proteins were transferred from the SDS gel to a nitrocellulose membrane (MSI) by using the Mini Trans-Blot Electrophoretic Transfer Cell (Bio-Rad) under constant voltage of $75 \mathrm{~V}$ for $4 \mathrm{~h}$ at $4{ }^{\circ} \mathrm{C}$. The efficiency of transfer was checked by staining the gel with Coomassie Blue. Blots were probed with a polyclonal antibody against human stomatin protein (Stewart et al., 1992) used at a $1: 1000$ dilution followed by secondary antibody (goat anti-rabbit IgG conjugated with horseradish peroxidase, Bio-Rad; dilution $1: 3000)$. Bound antigen was visualized by chemiluminescence using the ECL Western blotting detection reagents (Amersham Life Science).

Nodulation competition assay. Phaseolus beans (cv. Brazil 2) were grown in Leonard jar assemblies containing nitrogenfree nutrient solution as described previously (Borthakur \& Gao, 1996). Eight replicates were used for each treatment with each Leonard jar containing two bean seedlings. One-weekold seedlings were inoculated with $10^{6}$ rhizobia diluted with sterile plant nutrient solution from a 2-d-old culture. Three inoculant ratios, $1: 1,1: 9$ and $9: 1$, between each mutant and TAL182 were used for competition studies. Plate counts of the rhizobia were made to verify the ratios of the mutants and TAL182 in the mixtures. A few plants were grown as uninoculated controls to check for cross-contamination. Plants were placed in a completely randomized block design. The uninoculated control plants appeared chlorotic and did not have root nodules, indicating that there was no crosscontamination of rhizobia between jar assemblies. Plants were harvested 4 weeks after inoculation for nodule typing.

\section{RESULTS}

\section{Sequence analysis of the $4.6 \mathrm{~kb}$ Hind III fragment of pUHR207 and identification of three ORFs}

The $4.6 \mathrm{~kb}$ HindIII fragment of plasmid pUHR207 that complemented the competition-defective mutant RUH120 was sequenced (Fig. 1). Sequence analysis showed three ORFs in this region. orf1 is 2397 bp long and oriented in a right-to-left direction, extending beyond the $4.6 \mathrm{~kb}$ HindIII fragment by 282 bp at its $3^{\prime}$ end to the adjacent fragment, whereas orf 2 and orf 3 are oriented left-to-right. The gap between orf1 and orf 2 is $12 \mathrm{bp}$, while orf 2 and orf 3 are separated by $120 \mathrm{bp}$. orf 1 has $32 \%$ identity and $47 \%$ similarity with the $y 4 l L$ gene with unknown function from the symbiosis plasmid of Rhizobium sp. NGR234 (data not shown). orf2 is $1404 \mathrm{bp}$, encodes a protein of 467 amino acids with a calculated molecular mass of $48870 \mathrm{Da}$ and has no significant homology with any known protein in the database.

\section{orf3 encodes a stomatin-like protein}

orf3 is $669 \mathrm{bp}$ and its deduced amino acid sequence shows $66-72 \%$ similarity with the erythrocyte band 7 integral membrane protein or the stomatin protein of Homo sapiens, Mus musculus and Caenorhabditis elegans (Fig. 2). Because of this high homology of the deduced amino acid sequence with the stomatin protein, orf3 was named slp (stomatin-like protein). Like the human stomatin protein, the deduced slp gene product, Slp, is very hydrophilic except for a single hydrophobic domain at the C-terminus. However, unlike the human stomatin protein, Slp does not have the N-terminal transit peptide and is smaller in size (Fig. 3). When the slp gene was expressed from a T7 promoter in E. coli, a $26 \mathrm{kDa}$ protein was seen (Fig. 4a). The overexpressed Slp in E. coli cross-reacted with a polyclonal antibody specific for human stomatin protein (Fig. 4b), although the same antibody did not show detectable levels of cross-reaction with TAL182 proteins (data not shown).

\section{Insertional inactivation analysis of orf1, orf2 and the s/p gene in TAL182}

Mutants RUH127 and RUH126 were constructed by insertional inactivation of orf1 and orf3, respectively, in TAL182. In the mutant RUH127, orf1 was disrupted with the plasmid vector pBR322 through a single homologous recombination whereas in RUH126, the slp gene was interrupted by the $\operatorname{Kan}^{\mathbf{R}}$ cassette through double homologous recombination (see Methods). Southern hybridization confirms that the mutant RUH127 contains a pBR322 insertion in orf1 and the mutant RUH126 contains a $\mathrm{Kan}^{\mathbf{R}}$ cassette insertion within the slp gene (data not shown). The competitiondefective mutant RUH120 which was described previously (Borthakur \& Gao, 1996) contains a Tn5 insertion in orf2. The precise location of the $\operatorname{Tn} 5$ insertion in RUH120 was also determined by sequencing. The Tn5 insertion was located 259 nucleotides downstream from the beginning of this orf2 (Fig. 1). Mutants RUH120, RUH126 and RUH127 showed similar colony morphologies and growth rates in complete or minimal media.

\section{The s/p gene is required for nodulation competition on beans}

orf1 mutant RUH127 and slp mutant RUH126 formed normal nitrogen-fixing nodules on beans which were indistinguishable in number, size, shape and colour from those formed by TAL182. These mutants were tested for nodulation competition with TAL182 by coinoculating beans in paired combinations using different ratios of the two strains. The results of this experiment suggest that only RUH126, and not RUH127, is defective 


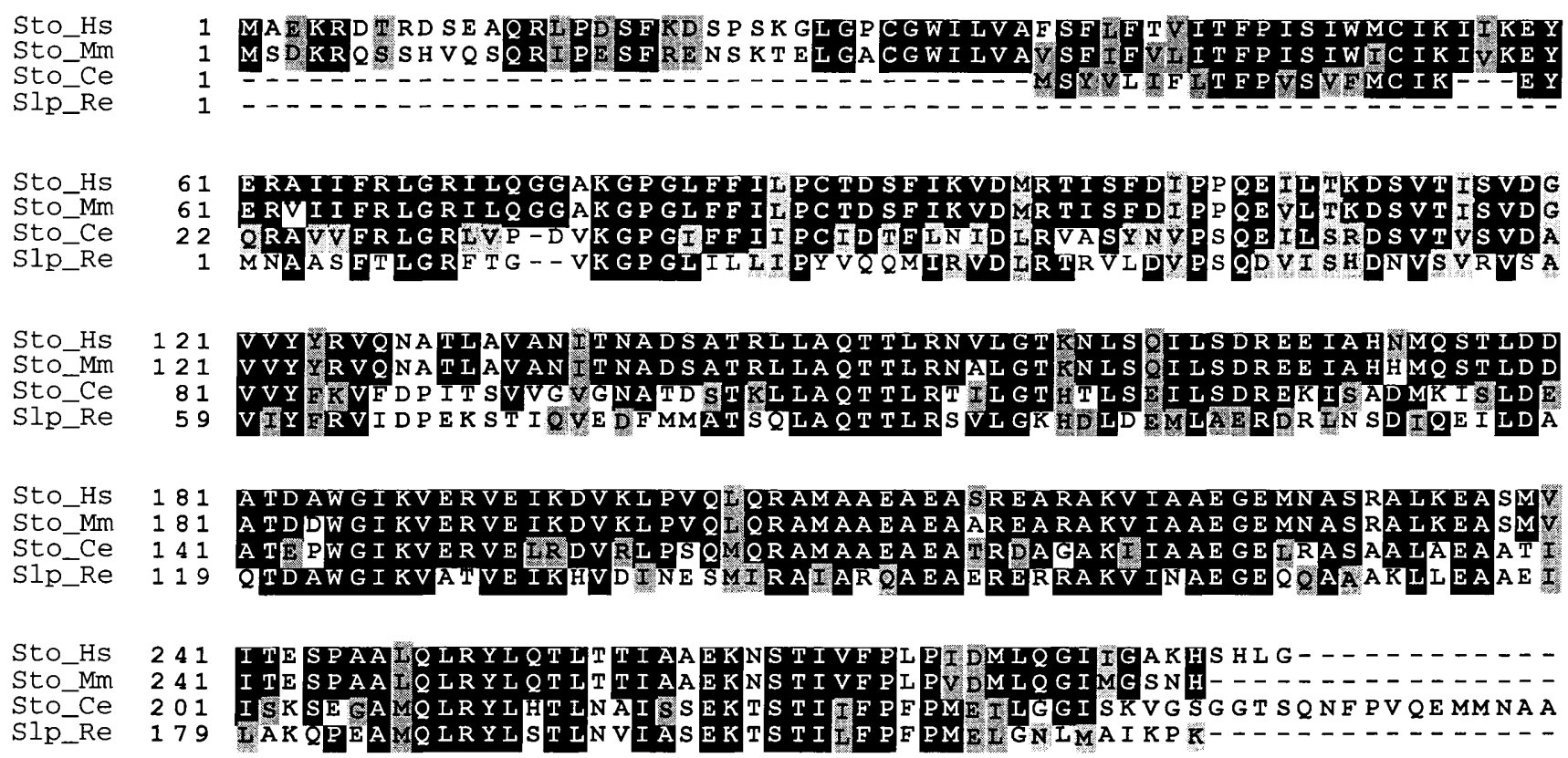

Fig. 2. Sequence comparison of deduced amino acid sequences from the $s / p$ gene of $R$. et/i (S/p_Re) and the stomatin genes of H. sapiens (Sto_Hs) (Stewart et al., 1992), M. musculus (Sto_Mm) (Gallagher et al., 1996) and C. elegans (Sto_Ce) (Wilkinson-Sproat \& Wohldman, 1994). Conserved residues are indicated by black areas, and similar residues are indicated by stippled areas.

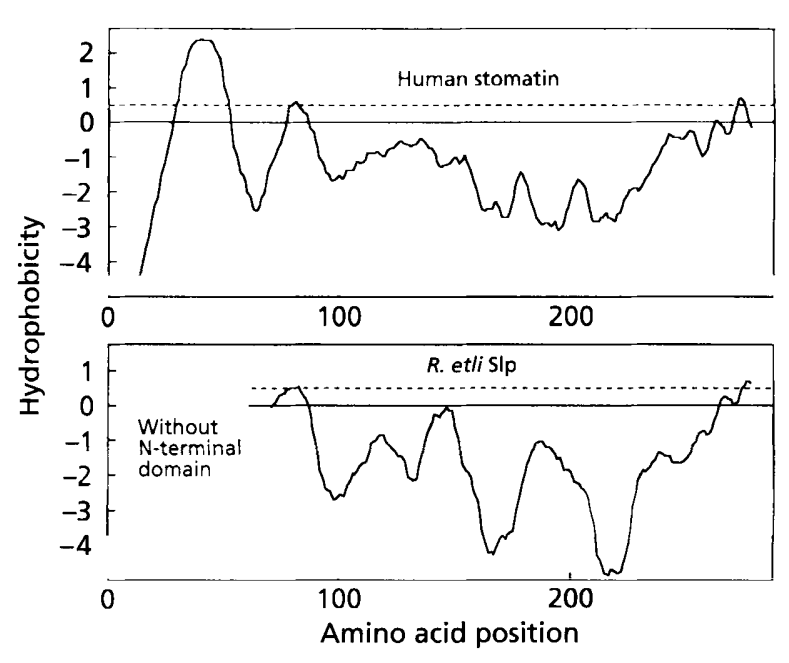

Fig. 3. Comparison of the hydropathy plots of $R$. etli Slp with human stomatin protein (Stewart et al., 1992) using the TopPred II computer program with a window of 21 amino acids (Claros \& von Heijne, 1994).

in nodulation competitiveness on beans (Table 2). Plasmid pUHR207 containing the $4.6 \mathrm{~kb}$ cloned DNA complemented RUH126 for nodulation competitiveness (Table 2).

\section{Growth of the $R$. etli s/p mutant RUH126 is inhibited by monovalent salts}

In humans, the stomatin gene is involved in the regulation of transport of sodium and potassium ions in the red blood cells (Stewart, 1997). To determine if the slp gene is also involved in the transport of monovalent ions in $R$. etli, the wild-type strain TAL182, mutant RUH126 and the transconjugant of RUH126 containing pUHR207 were grown in minimal medium containing $\mathrm{NaCl}, \mathrm{KCl}$ or LiCl. Compared to TAL182, the rate of growth and the final cell density of RUH126 were reduced in the presence of $200 \mathrm{mM} \mathrm{NaCl}, \mathrm{KCl}$ or $\mathrm{LiCl}$ in the medium (Fig. 5). The growth of the transconjugant RUH126(pUHR207) in the presence of these salts was similar to that of TAL182, indicating that the slp gene in pUHR207 complemented the growth defect in RUH126 due to the presence of monovalent salts. These observations suggest that the $s l p$ gene may be involved in ion transport in $R$. etli. When osmotic stress was applied to TAL182, RUH126 and RUH126(pUHR207) for $15 \mathrm{~min}$ to $3 \mathrm{~h}$, all three strains showed similar survival rates as judged from the colony counts from plating (data not shown). This indicates that the slp mutant does not have osmotic defects.

\section{The s/p gene is not present in all rhizobia}

Southern analysis of genomic DNA of strains of various Rhizobium, Bradyrbizobium and Sinorbizobium species using the $s$ lp gene of TAL182 as the probe showed the absence of any hybridizing bands in $B$. japonicum USDA110, Rbizobium (Aeschynomene) strain Btai1, Rhizobium leguminosarum bv. trifolii WU290, Rhizobium sp. NGR234 and the $R$. tropici type B strains (Fig. 6). The slp probe hybridized with strains of $R$. leguminosarum bv. viciae, $R$. leguminosarum bv. phaseoli, S. meliloti, R. etli, Rhizobium fredii and $R$. 

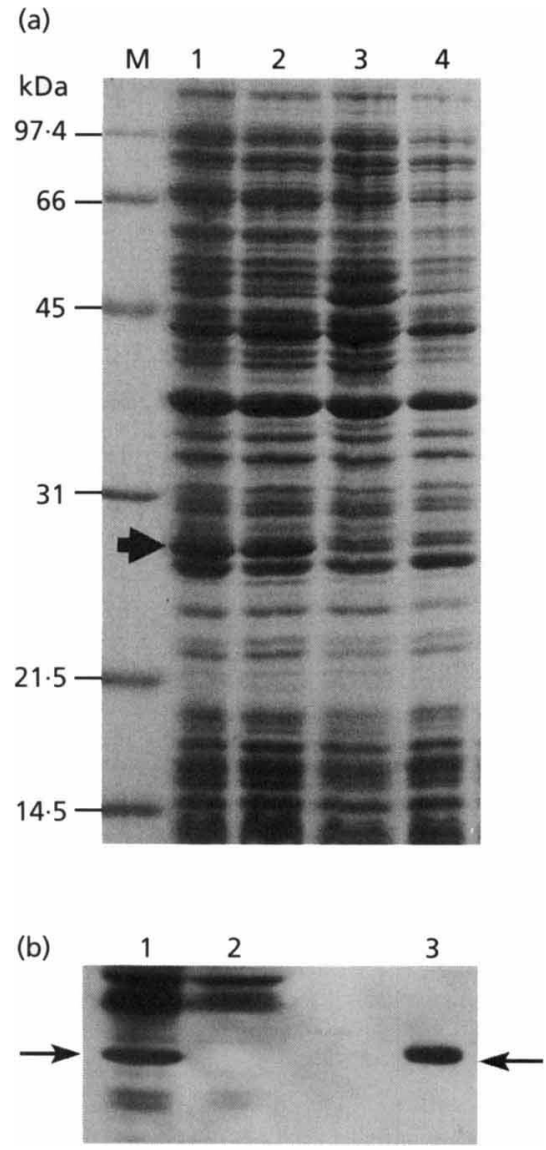

Fig. 4. (a) Expression of $R$. etli Slp in $E$. coli. Strain BL21(DE3)pLysS containing the cloned s/p gene in plasmid pET21-669 was grown with IPTG for 2 and $3 \mathrm{~h}$ (lanes 1 and 2), or without IPTG for $3 \mathrm{~h}$ (lane 3). Extract from strain BL21(DE3)pLysS without additional plasmid grown for $3 \mathrm{~h}$ was loaded in lane 4 as a control. An additional protein band corresponding to $26 \mathrm{kDa}$ in lanes 1 and 2 is indicated with an arrow. Size markers are in lane M. (b) Western blot analysis of overexpressed SIp in E. coli cross-reacting with human-stomatinspecific polyclonal antibody. The antibody cross-reacted with the overexpressed $26 \mathrm{kDa}$ Slp (indicated with an arrow) and some other $E$. coli proteins in lane 1 . The $26 \mathrm{kDa}$ band was absent in the extract from the uninduced culture (lane 2). When the overexpressed $26 \mathrm{kDa}$ Slp band was excised from a protein gel and reloaded on the protein gel, it again crossreacted with the antibody (lane 3 ).

tropici type A strains. Among several bean-nodulating Rbizobium strains from the NifTAL collection (TAL strains), the slp gene did not hybridize with TAL490, TAL617 and Rhizobium sp. strain TAL1145.

\section{DISCUSSION}

The slp gene isolated in this study is required for nodulation competition on beans. The deduced amino acid sequence of the slp gene shows high homology with the human and murine stomatin peptides. Therefore, it was not surprising that the polyclonal antibody raised against human stomatin protein also cross-reacted with the overexpressed Slp in E. coli. This suggests that at least some epitopes of the two proteins are similar. The Slp may be expressed at a very low level in TAL182 since the stomatin-specific antibody did not detect the presence of this protein in this strain in the Western blot analysis using a non-radioactive detection system. The antibody also cross-reacted with some $E$. coli proteins because it was produced by injecting rabbits with purified human stomatin protein expressed in E. coli (Stewart et al., 1992). It is likely that during purification from $E$. coli, the stomatin protein was slightly contaminated with $E$. coli proteins. Human stomatin is an integral membrane protein involved in ion conductance across the membrane of red blood cells (Stewart $e t$ al., 1992). It may be a part of the junctional complex of the membrane skeleton. In the absence of this protein, as in the case of a rare haemolytic anaemia, hereditary stomatocytosis, red blood cells leak sodium and potassium ions, suggesting that the protein has a role in the regulation of ion transport (Stewart, 1997). The Rhizobium slp gene also shows high homology with the mec-2 gene of the soil nematode Caenorhabditis elegans, encoding a stomatin-like protein MEC-2 (Huang et al., 1995). MEC-2 positively regulates the degenerin channel affecting the touch receptor axons of this nematode. MEC-2 links the mechanosensory degenerin channel and the microtubule cytoskeleton of the touch receptor neurons. The mec-2 mutants are touch-insensitive. Thus, both stomatin and MEC-2 are membraneassociated proteins and interact with other proteins to regulate ion or mechanosensory channels. Slp, on the other hand, is a cytoplasmic protein with only one membrane-spanning domain at the C-terminus. It is different from both stomatin and MEC-2 in that it does not have an N-terminal hydrophobic membrane-spanning domain. The function of the missing N-terminal hydrophobic domain may be substituted by other membrane-associated proteins with which Slp interacts.

The striking sequence similarity between Slp and stomatin suggests that Slp has a similar function. This hypothesis is consistent with our finding that the slp mutant grows slower than the wild-type in medium containing $200 \mathrm{mM} \mathrm{NaCl}, \mathrm{KCl}$ or LiCl. Stomatin is thought to inhibit membrane conductance whereas Slp may be involved in the transport of ions, which is coupled with nutrient uptake. Thus, the slp gene may provide a growth or competition advantage to the Rhizobium strain in the infection thread. The mutant RUH126 without Slp may have a disadvantage in ion exchange and nutrient uptake in the infection thread, resulting in the loss of capacity for competition for nodule invasion. However, Slp may not be a member of a primary ion channel system because the $s / p$ gene is not present in all rhizobia: a gene involved in a primary transport system is expected to be present in all rhizobia. Moreover, a mutation in a gene involved in a primary transport system should severely affect the growth of the mutant.

The slp gene is not essential for nodulation and nitrogen fixation because the mutant RUH126 forms nitrogenfixing nodules on beans. Similarly, R. tropici type B 
Table 2. Competitive nodule occupancies of $R$. etli strains on beans in paired inoculation experiments

\begin{tabular}{|c|c|c|c|c|}
\hline \multicolumn{2}{|c|}{ Co-inoculated strains } & \multirow{2}{*}{$\begin{array}{c}\text { Ratio } \\
A: B\end{array}$} & \multicolumn{2}{|c|}{ Nodule occupancy $(\%)^{*}$ by: } \\
\hline A & B & & A & B \\
\hline \multirow[t]{3}{*}{ TAL182 } & RUH126 & $9: 1$ & $99 \cdot 7 \pm 1 \cdot 0$ & $0 \cdot 3 \pm 1 \cdot 0$ \\
\hline & & $1: 1$ & $94 \cdot 8 \pm 3 \cdot 7$ & $4 \cdot 9 \pm 3 \cdot 7$ \\
\hline & & $1: 9$ & $84 \cdot 4 \pm 6 \cdot 4$ & $15 \cdot 6 \pm 6 \cdot 4$ \\
\hline \multirow[t]{3}{*}{ RUH126(pUHR207) } & RUH126 & $9: 1$ & $95 \cdot 4 \pm 2 \cdot 5$ & $4 \cdot 6 \pm 2 \cdot 5$ \\
\hline & & $1: 1$ & $73 \cdot 5 \pm 6 \cdot 8$ & $26 \cdot 5 \pm 6 \cdot 8$ \\
\hline & & $1: 9$ & $30 \cdot 0 \pm 5 \cdot 5$ & $70 \cdot 0 \pm 5 \cdot 5$ \\
\hline \multirow[t]{3}{*}{ TAL182 } & RUH127 & $9: 1$ & $85 \cdot 0 \pm 3 \cdot 6$ & $15 \cdot 0 \pm 3 \cdot 6$ \\
\hline & & $1: 1$ & $51 \cdot 4 \pm 10$ & $48 \cdot 6 \pm 10$ \\
\hline & & $1: 9$ & $12 \cdot 1 \pm 3 \cdot 2$ & $87 \cdot 9 \pm 3 \cdot 2$ \\
\hline
\end{tabular}

*Data are means \pm SD from eight replicates.
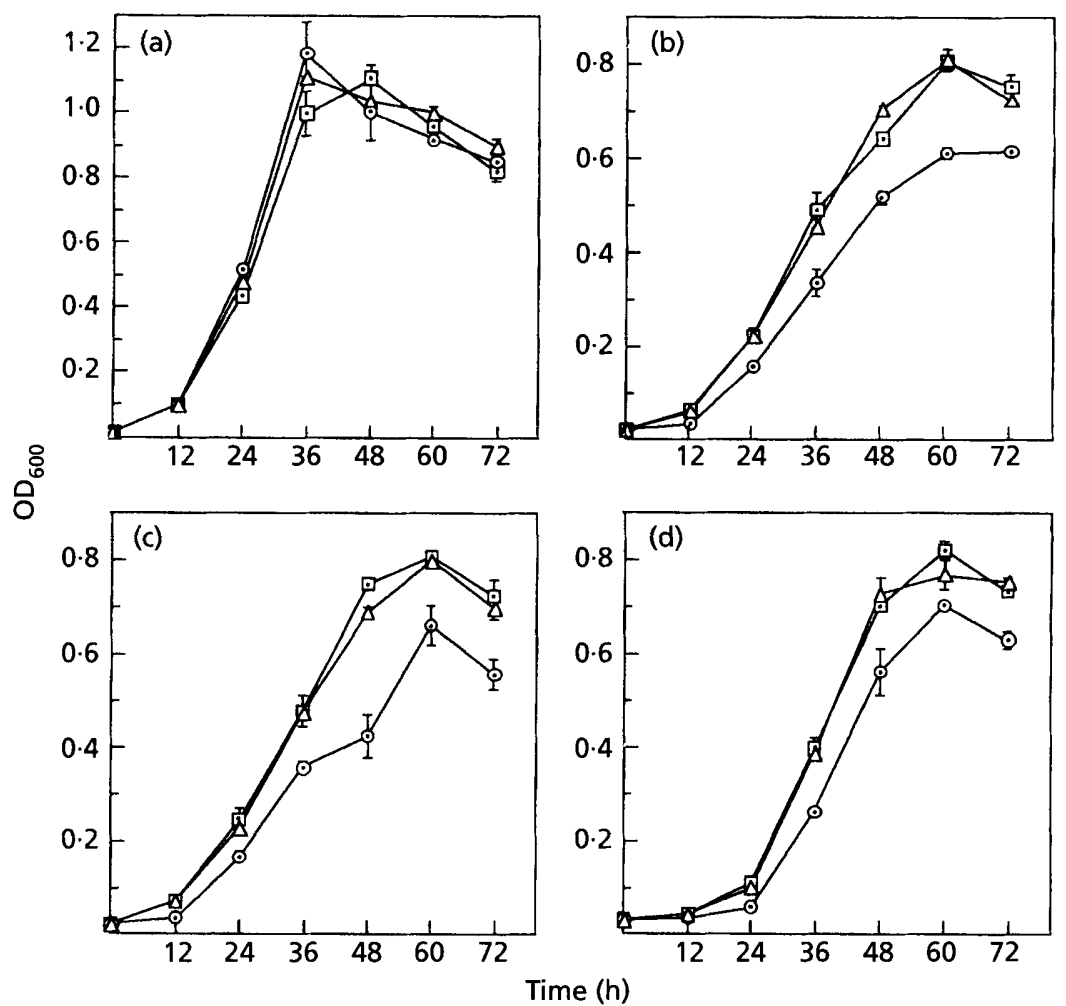

Fig. 5. Growth of R. etli TAL182 ( $\square$ ), mutant RUH126 (O) and RUH126 containing pUHR207 $(\triangle)$ in $M M(a)$, and in $M M$ containing $200 \mathrm{mM} \mathrm{NaCl}$ (b), $200 \mathrm{mM} \mathrm{KCl}$ (c) or $200 \mathrm{mM} \mathrm{LiCl}(d)$. strains and several other bean-nodulating strains such as TAL1145, TAL490 and TAL617 do not have the slp gene, and yet form effective nodules on beans. In these strains, the function of the slp gene may be substituted by another gene. In the absence of an slp-like gene or a substitute with similar function, the $R$. tropici type $\mathrm{B}$ strains may be less competitive for nodule occupancy on beans. In competition experiments involving $R$. tropici CIAT899 and $R$. etli TAL182 on beans, the latter was found to occupy most of the nodules (Borthakur \& Gao, 1996). There is no homologue of slp in Rhizobium sp. strain TAL1145, which nodulates both tree legumes and beans. This may be one of the reasons for the inability of this strain to occupy bean nodules when co-inoculated with TAL182. Besides $s$ lp, there might be other genes involved in nodulation competition in TAL182, because the capacity to occupy bean nodules in competition with TAL182 was only partially enhanced in transconjugants of TAL1145 containing the cosmid clone which contained slp (Borthakur \& Gao, 1996).

The mutant RUH126 is similar to TAL182 except for the insertion of the $\operatorname{Kan}^{\mathrm{R}}$ cassette into the slp gene. The strain was used to nodulate beans and was reisolated 

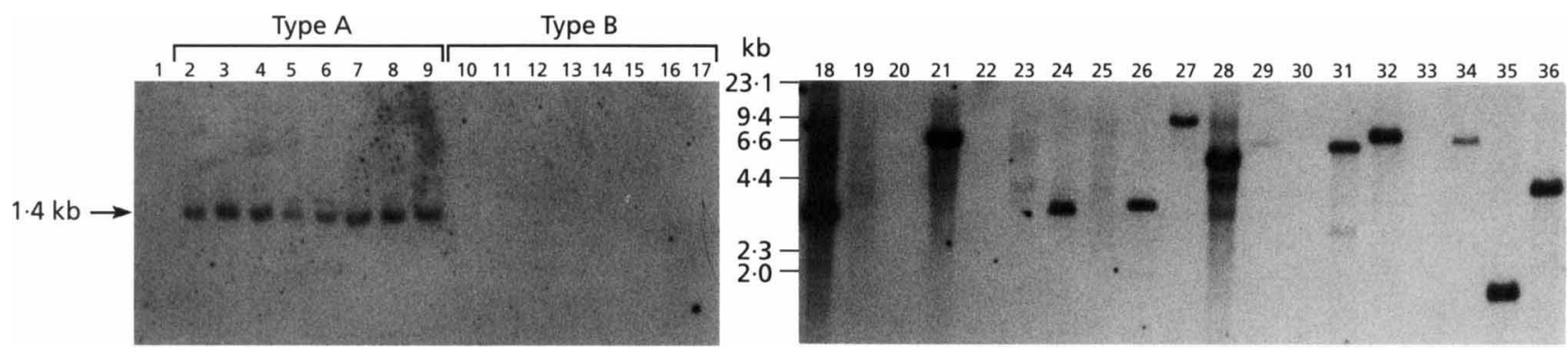

Fig. 6. Southern hybridization of EcoRl-digested genomic DNA from various rhizobia with a 576 bp PCR-generated fragment from TAL182 containing sip sequences as the probe. The type A and type B strains of $R$. tropici are indicated. 1. TAL1145; 2, BR828; 3, BR833; 4, BR835; 5, BR836; 6, BR842; 7, BR846; 8, CFN299; 9, BR10043; 10, BR847; 11, BR850; 12, BR852; 13, BR857; 14, BR858; 15, BR859; 16, BR863; 17, BR864; 18, TAL182; 19, USDA110 (B. japonicum); 20, Btai1 (Aeschynomene); 21, F4B94 (R. leguminosarum bv. viciae); 22, NGR234; 23, CIAT899 (R. tropici type B); 24 , NZP4013 (S. meliloti); 25, WU290 ( $R$. leguminosarum bv. trifolii); 26, CE3 $(R$. et $I i) ; 27$, USDA205 ( $R$. fredii); 28,8002 ( $R$. leguminosarum bv. phaseoli); 29, TAL459; 30, TAL490; 31, TAL660; 32, TAL664; 33, TAL617; 34, TAL1140; 35, TAL1242; 36, TAL663.

from nodules before it was used in competition experiments. During the process it was cured of the plasmid pPH1JI, which was used to homogenotize the $\mathrm{Kan}^{\mathrm{R}}$ cassette insertion. The competition defect of this mutant is not due to the kanamycin cassette insertion per se but to the interruption in the slp gene, because it is complemented by the plasmid pUHR207 containing a cloned slp gene. Contrary to the competition-defective phenotype of RUH126, mutant RUH127, in which orf1 was interrupted with the plasmid pBR322, was found to be not defective for nodulation competition on beans. In the competition experiments involving RUH126, the extent of double occupancies of nodules was not determined. It is possible that a few nodules occupied by the $\mathrm{Kan}^{\mathrm{K}}$ mutant were also inhabited by TAL182. In an experiment involving mutant RUH127, which has a tetracycline-resistance marker, the extent of double occupancies was estimated to be $5 \pm 3 \%$. Our competition experiments with beans were conducted in growth chambers under controlled conditions, which are different from those found in the field. However, in the present study we address competition as an aspect of nodule invasion which includes initial entry of rhizobia into the root cells through infection thread, followed by growth and proliferation through the infection thread and final release of rhizobia into the infected cells of the developing nodules. To avoid other aspects of interstrain competition in the rhizosphere favouring survival or death of any one strain before initial infection, we used an excess amount of rhizobia (at least $10^{6}$ cells) for inoculating each Leonard jar assembly. Therefore, our results from the controlled growth room situation should indicate what does happen during nodule invasion in the natural soil environment.

\section{ACKNOWLEDGEMENTS}

This research was supported by USDA-NRI grant 92-373057875 and partly by USDA-CSRS TSTAR grant 95-34135-1766. We wish to thank Leslie R. Berger for critically reading the manuscript and Gordon W. Stewart for useful discussion.
Paper 4338 of the College of Tropical Agriculture and Human Resources, University of Hawaii, Honolulu.

\section{REFERENCES}

Altschul, S. F., Gish, W., Miller, W., Myers, E. W. \& Lipman, D. J. (1990). Basic local alignment search tool. J Mol Biol 215, 403-410.

Beattie, G. A. \& Handelsman, J. (1993). Evaluation of a strategy for identifying nodulation competitiveness genes in Rhizobium leguminosarum biovar phaseoli. J Gen Microbiol 139, 529-538.

Borthakur, D. \& Gao, X. (1996). A 150-megadalton plasmid in Rhizobium etli strain TAL182 contains genes for nodulation competitiveness on Phaseolus vulgaris L. Can J Microbiol 42, 903-910.

Chun, J. Y. \& Stacey, G. (1994). A Bradyrbizobium japonicum gene essential for nodulation competitiveness is differentially regulated from two promoters. Mol Plant-Microbe Interact 7, $248-255$.

Claros, M. G. \& von Heijne, G. (1994). TopPred II: an improved software for membrane protein structure predictions. Comput Appl Biosci 10, 685-686.

Gallagher, P. G., Turetsky, T. \& Mentzer, W. C. (1996). Genomic organization and $5^{\prime}$-flanking DNA sequence of the murine stomatin gene (Epb72). Genomics 34, 410-412.

George, M. L. C., Robert, F. M. \& Borthakur, D. (1992). Genetic analysis of Rhizobium leguminosarum bv. phaseoli mutants defective in nodulation and nodulation suppression. Appl Environ Microbiol 58, 1050-1053.

George, M. L. C., Young, J. W. P. \& Borthakur, D. (1994). Genetic characterization of R hizobium sp. strain TAL1145 that nodulates tree legumes. Can J Microbiol 40, 208-215.

Hirsch, A. M. (1992). Developmental biology of legume nodulation. New Phytol 122, 211-237.

Huang, M., Gu, G., Ferguson, E. L. \& Chalfie, M. (1995). A stomatin-like protein necessary for mechanosensation in $C$. elegans. Nature 378, 292-295.

Leigh, J. A. \& Coplin, D. L. (1992). Exopolysaccharides in plantbacterial interactions. Annu Rev Microbiol 46, 307-346.

Long, S.R. (1996). Rhizobium symbiosis: Nod factors in perspective. Plant Cell 8, 1885-1898.

Martínez-Romero, E., Segovia, L., Mercante, F. M., Franco, A. A., 
Graham, P. \& Pardo, M. A. (1991). Rhizobium tropici, a novel species nodulating Phaseolus vulgaris L. beans and Leucaena sp. trees. Int J Syst Bacteriol 41, 417-426.

Mavingui, P., Flores, M., Romero, D., Martínez-Romero, E. \& Palacios, R. (1997). Generation of Rhizobium strains with improved symbiotic properties by random DNA amplification (RDA). Nature Biotechnol 15, 564-569.

Sambrook, J., Fritsch, E. F. \& Maniatis, T. (1989). Molecular Cloning: a Laboratory Manual, 2nd edn. Cold Spring Harbor, NY: Cold Spring Harbor Laboratory.

Sanjuan, J. \& Olivares, J. (1991). NifA-NtrA regulatory system activates transcription of $n f e$, a gene locus involved in nodulation competitiveness of Rhizobium meliloti. Arch Microbiol 155, 543-548.

Shapira, S. K., Chou, J., Richaud, F. V. \& Casadaban, M. J. (1983). New versatile plasmid vectors for expression of hybrid proteins coded by a cloned gene fused to lac $Z$ gene sequences encoding an enzymatically active carboxy-terminal portion of $\beta$-galactosidase. Gene 25, 71-82.

Soedarjo, M. \& Borthakur, D. (1998). Mimosine, a toxin produced by the tree-legume Leucaena provides a nodulation competition advantage to mimosine-degrading Rhizobium strains. Soil Biol Biochem 30, 1605-1613.
Soto, M. J., Zorzano, A., Mercado-Blanco, J., Lepek, V., Olivares, J. \& Toro, N. (1993). Nucleotide sequence and characterization of Rhizobium meliloti nodulation competitiveness genes nfe. J Mol Biol 229, 570-576.

Stewart, G. W. (1997). Stomatin. Int J Biochem Cell Biol 29, 271-274.

Stewart, G. W., Hepworth-Jones, B. E., Keen, J. N., Dash, B. C. J., Argent, A. C. \& Casimir, C. M. (1992). Isolation of cDNA coding for an ubiquitous membrane protein deficient in high $\mathrm{Na}^{+}$, low $\mathrm{K}^{+}$ stomatocytic erythrocytes. Blood 79, 1593-1601.

Studier, F. W. \& Moffatt, B. A. (1986). Use of bacteriophage T7 RNA polymerase to direct selective high level expression of cloned genes. J Mol Biol 189, 113-130.

Thorne, S. H. \& Williams, H. D. (1997). Adaptation to nutrient starvation in Rhizobium leguminosarum bv. phaseoli : analysis of survival, stress resistance, and changes in macromolecular synthesis during entry to and exit from stationary phase. J Bacteriol 179, 6894-6901.

Wilkinson-Sproat, J. \& Wohldman, P. (1994). $2 \cdot 2 \mathrm{Mb}$ of contiguous nucleotide sequence from chromosome III of C. elegans. Nature $368,32-38$.

Received 21 April 1998; revised 19 May 1998; accepted 21 May 1998. 